\title{
Intra-and interspecific karyotypic variations of the genus Senna Mill. (Fabaceae, Caesalpinioideae)
}

\author{
Joel Maciel Pereira Cordeiro ${ }^{1 *}$ and Leonardo P. Felix ${ }^{1}$
}

Received: July 25, 2017

Accepted: September 25, 2017

\begin{abstract}
Although the chromosome number $2 n=28$ predominates in most species of the genus Senna, variations are often observed, resulting from either polyploidy $(2 n=42,56,112)$ or disploidy $(2 n=22,24,26)$ events. To better understand the karyotypic variations in Senna, we examined heterochromatin patterns of 10 species of that genus using chromomycin A3 (CMA) and 4'6-diamidino-2-phenylindole (DAPI) staining, and reviewed information on the chromosome counts of 72 species of that genus. The CMA/DAPI banding patterns were relatively variable among the 10 species, both in terms of the numbers of bands (from two to 26) and their locations on the chromosomes (terminal or proximal regions). Our review indicated that $2 n=28$ is the most common ploidy among species of Senna, although other numbers were observed, apparently due to polyploidy or disploidy events; polysomy and aneusomy were also observed. Karyotype variations appear to have contributed to the diversification and wide distribution of Senna.
\end{abstract}

Keywords: Chromosome number, CMA/DAPI, disploidy, Leguminosae, polyploidy

\section{Introduction}

Senna is one of the most diverse genera within the family Fabaceae, with approximately 350 species of trees, shrubs, and sub-shrubs distributed throughout the American, African, and Australian continents, with occurrences also in Asia and on Pacific islands (Irwin \& Barneby 1982; Marazzi et al. 2006). Species occupy an extremely wide range of habitats, varying from humid forests, dry forests, rock outcrops, dry or cold deserts to anthropized areas (Irwin \& Barneby 1982; Acharya et al. 2011).

Phylogenetic analyses have demonstrated that Senna is monophyletic and occupies a position near Cassia senso stricto and Chamaecrista (Marazzi et al. 2006; Acharya et al. 2011). Those three genera form the subtribe Cassiinae Irwin \& Barneby, and they are morphologically distinguished in relation to characteristics of their androceu, corolla, floral architecture, bracteoles, and fruits. Senna has traditionally been divided into six sections: Astroites, Chamaefistula, Paradictyon, Peiranisia, Psilorhegma, and Senna, based on their floral morphologies and fruit and extrafloral nectary structures (Irwin \& Barneby 1982), although examinations of the DNA sequences of different chloroplast gene regions ( $r p S 16, r p L 16$, matK) have demonstrated that most of those sections are polyphyletic (Marazzi et al. 2006).

Chromosome counts are available for approximately $20 \%$ of the species of Senna, with a predominance of $2 n=$ 28 , although there are also records of $2 n=22,24$ and 26 (Goldblatt 1981; Souza \& Benko-Iseppon 2004; Biondo et al. 2005a; Matos et al. 2011; Resende et al. 2013; Rice et al. 2015); records of polyploidy, such as $2 n=42,56$ and 112 in Senna rugosa (Resende et al. 2014), $2 n=56$ in S. aversiflora, and $2 n=52$ and 104 in S. gardneri (Matos et al. 2011) have

1 Departamento de Ciências Biológicas, Centro de Ciências Agrárias, Universidade Federal da Paraíba, Campus II, PB 079, Km 12, 58397-000, Areia, PB, Brazil

* Corresponding author: joelmpcordeiro@yahoo.com.br 
also been cited. The consistent record of $2 n=28$ for most species demonstrates that the basic number may be $x=14$, while the other numbers ( $x=11,12$ and 13) apparently reflect disploidy events (Goldblatt 1981).

Karyotypic analyses of representatives of Senna using fluorochromes have been relatively scarce, with the exception of work by Souza \& Benko-Iseppon (2004). Those authors reported the occurrence of two chromosome pairs with terminal or subterminal $\mathrm{CMA}^{+} / \mathrm{DAPI}^{-}$bands in most of the species analyzed, with the exception of a population of Senna obtusifolia (which demonstrated two chromosome pairs with terminal $\mathrm{DAPI}^{+} / \mathrm{CMA}^{-}$bands). Studies of heterochromatin patterns can be important tools for understanding the taxonomic relationships between different plant species, especially those that are morphologically very similar (Pessoa et al. 2014; Almeida et al. 2016; Cordeiro et al. 2016).

In order to understand the role of karyotype differentiation and evolutionary trends in this genus, we analyzed the heterochromatin patterns of 10 species of Senna (Fabaceae, Caesalpinioideae) using the fluorochromes chromomycin A3 (CMA) and 4'6-diamidino-2-phenylindole (DAPI) and reviewed the chromosome numbers of 72 species of that genus (and performed first counts for two species) for evidence of polyploidy, disploidy, and intra- and interspecific variations.

\section{Materials and methods}

\section{Taxonomic sampling}

We examined variations in the chromosome numbers of 74 species of the genus Senna based on chromosome counts published in the literature and on work presented here. The species names, authors, and references are listed in Table 1. For those species whose counts were exclusively obtained from the Chromosome Counts Database (CCDB, Rice et al. 2015), we present only the predominant chromosome count.

Cytogenetic analyses were performed on ten species of the genus Senna growing in areas of Caatinga (dryland) and humid forest vegetation in the Agreste region of Paraíba State, northeastern Brazil, to determine their heterochromatin patterns. Prepared samples of collected specimens were deposited in the Professor Jayme Coelho de Moraes Herbarium (EAN) of the Federal University of Paraíba. Detailed information concerning the species and their main karyological features are listed in Table 2. Seeds from the collected species were sown to germinate in Petri dishes. After their roots had grown to approximately 1.5 $\mathrm{cm}$ in length, they were excised and treated as described below. At least 10 roots per species were analyzed.

Table 1. Chromosome records of species of the genus Senna, and their respective references.

\begin{tabular}{|c|c|c|}
\hline Taxon Name & Cromosome number $(2 n)$ & Source \\
\hline Senna acuruensis (Benth.) H.S.Irwin \& Barneby var. acuruensis & 28 & Matos et al. 2011 \\
\hline S. alata (L.) Roxb. & 28 & $\begin{array}{l}\text { Biondo et al. 2005a; Resende et al. 2013; Souza \& Ben- } \\
\text { ko-Iseppon 2004; Present work }\end{array}$ \\
\hline S. alexandrina Mill. & 28 & Rice et al. 2015 \\
\hline S. angulata (Vogel) H.S.Irwin \& Barneby & 26 & Biondo et al. 2005a \\
\hline S. appendiculata (Vogel) Wiersema & 28 & Rice et al. 2015 \\
\hline S. araucarietorum H.S.Irwin \& Barneby & 28 & Biondo et al. 2005a \\
\hline S. armata (S. Watson) H.S.Irwin \& Barneby & 28 & Rice et al. 2015 \\
\hline S. artemisioides (Gaudich. ex DC.) Randell & 28 & Rice et al. 2015 \\
\hline S. artemisioides subsp. circinnata (Benth.) Randell & 56 & Rice et al. 2015 \\
\hline S. artemisioides subsp. zygophylla (Benth.) Randell & 42 & Rice et al. 2015 \\
\hline S. atomaria (L.) H.S.Irwin \& Barneby & 24 & Rice et al. 2015 \\
\hline S. auriculata Roxb. & 28 & Rice et al. 2015 \\
\hline S. aversiflora (Herb.) H.S.Irwin \& Barneby & 28,56 & Matos et al. 2011; Present work \\
\hline S. bicapsularis (L.) Roxb. & 28 & Rice et al. 2015 \\
\hline $\begin{array}{l}\text { S. birostris (Vogel) H.S.Irwin \& Barneby var. hookeri- } \\
\text { ana (Hook.) H.S.Irwin \& Barneby }\end{array}$ & 28 & Rice et al. 2015 \\
\hline S. bracteosa D.B.O.S.Cardoso \& L.P.Queiroz & 28 & Matos et al. 2011 \\
\hline S. cana (Nees \& Mart.) H.S.Irwin \& Barneby & 28 & Rice et al. 2015; Matos et al. 2011 \\
\hline S. candolleana (Vogel) H.S.Irwin \& Barneby & 24 & Rice et al. 2015 \\
\hline S. cernua (Balb.) H.S.Irwin \& Barneby & 28 & Biondo et al. 2005a; Resende et al. 2013 \\
\hline S. chrysocarpa (Desv.) H.S.Irwin \& Barneby & 24 & Rice et al. 2015 \\
\hline S. corymbosa (Lam.) H.S.Irwin \& Barneby & 28 & Biondo et al. 2005a; Resende et al. 2013 \\
\hline S. didymobotrya (Fresen.) H.S.Irwin \& Barneby & 28 & Rice et al. 2015 \\
\hline S. durangensis (Rose) H.S.Irwin \& Barneby & 28 & Rice et al. 2015 \\
\hline S. $\times$ floribunda (Cav.) H.S.Irwin \& Barneby & 28 & Rice et al. 2015 \\
\hline S. fruticosa (Mill.) H.S.Irwin \& Barneby & 28 & Rice et al. 2015 \\
\hline S. gardneri (Benth.) H.S.Irwin \& Barneby & $26,52,104$ & Matos et al. 2011 \\
\hline S. gaudichaudii (Hook. \& Arn.) H.S.Irwin \& Barneby & 28 & Rice et al. 2015 \\
\hline
\end{tabular}


Table 1. Cont.

\begin{tabular}{|c|c|c|}
\hline Taxon Name & Cromosome number $(2 n)$ & Source \\
\hline S. glutinosa (DC.) Randell & 42 & Rice et al. 2015 \\
\hline S. georgica H.S.Irwin \& Barneby & 26 & Present work \\
\hline S. hilariana (Benth.) H.S.Irwin \& Barneby & 28 & Biondo et al. 2005a \\
\hline S. hirsuta (L.) H.S.Irwin \& Barneby & 28 & Biondo et al. 2005a \\
\hline S. hirsuta (L.) H.S.Irwin \& Barneby var. hirta Irwin \& Barneby & 24 & Rice et al. 2015 \\
\hline S. holosericea (Fresen.) Greuter & 28 & Rice et al. 2015 \\
\hline S. insularis (Britton \& Rose) H.S.Irwin \& Barneby & 28 & Rice et al. 2015 \\
\hline S. italica Mill. & 28 & Rice et al. 2015 \\
\hline S. kurtzii (Harms) H.S.Irwin \& Barneby & 24 & Rice et al. 2015 \\
\hline S. macranthera (DC. ex Collad.) H.S.Irwin \& Barneby & 26 & Biondo et al. 2005a; Resende et al. 2013 \\
\hline S. martiana (Benth.) H.S.Irwin \& Barneby & 28 & Matos et al. 2011; Present work \\
\hline S. montana (B.Heyne ex Roth) V.Singh & 28 & Rice et al. 2015 \\
\hline S. multiglandulosa (Jacq.) H.S.Irwin \& Barneby & 24 & Rice et al. 2015 \\
\hline S. multijuga (Rich.) H.S.Irwin \& Barneby & 24 & Biondo et al. 2005a; Resende et al. 2013 \\
\hline S. neglecta (Vogel) H.S.Irwin \& Barneby & 28 & Biondo et al. 2005a \\
\hline S. nitida (Rich.) H.S.Irwin \& Barneby & 24 & Rice et al. 2015 \\
\hline S. oblongifolia (Vogel) H.S.Irwin \& Barneby & 28 & Biondo et al. 2005a \\
\hline S. obtusifolia (L.) H.S.Irwin \& Barneby & $24,26,28$ & $\begin{array}{l}\text { Biondo et al. 2005a; Souza \& Benko-Iseppon 2004; Rice } \\
\text { et al. 2015; Present work }\end{array}$ \\
\hline S. occidentalis (L.) Link & $24,26,28$ & $\begin{array}{l}\text { Biondo et al. 2005a; Matos et al. 2011; Rice et al. 2015; } \\
\text { Present work }\end{array}$ \\
\hline S. odorata (R. Morris) Randell & 28 & Rice et al. 2015 \\
\hline S. pallida (Vahl) H.S.Irwin \& Barneby & 28 & Rice et al. 2015 \\
\hline S. pendula (Willd.) H.S.Irwin \& Barneby & 28 & Biondo et al. 2005a; Resende et al. 2013 \\
\hline S. petersiana (Bolle) Lock & 28 & Rice et al. 2015 \\
\hline S. pilifera (Vogel) H.S.Irwin \& Barneby & 22 & Biondo et al. 2005a \\
\hline S. planitiicola (Domin) Randell & 28 & Rice et al. 2015 \\
\hline S. pleurocarpa (F.Muell.) Randell & 28 & Matos et al. 2011 \\
\hline S. podocarpa (Guill. \& Perrottet) Lock & 16 & Rice et al. 2015 \\
\hline S. polyantha (Collad.) H.S.Irwin \& Barneby & 28 & Rice et al. 2015 \\
\hline S. quinquangulata (Rich.) H.S.Irwin \& Barneby & 26 & Souza \& Benko-Iseppon 2004 \\
\hline S. reticulata (Willd.) H.S.Irwin \& Barneby & 28 & Souza \& Benko-Iseppon 2004 \\
\hline S. rizzinii H.S.Irwin \& Barneby & 26 & Present work \\
\hline S. roemeriana (Scheele) H.S.Irwin \& Barneby & 28 & Rice et al. 2015 \\
\hline S. rugosa (G. Don) H.S.Irwin \& Barneby & $42,56,112$ & Biondo et al. 2005a; Resende et al. 2014 \\
\hline S. septemtrionalis (Viv.) H.S.Irwin \& Barneby & 28 & Biondo et al. 2005a \\
\hline S. siamea (Lam.) H.S.Irwin \& Barneby & 28 & $\begin{array}{l}\text { Resende et al. 2013; Souza \& Benko-Iseppon 2004; } \\
\text { Matos et al. 2011; Present work }\end{array}$ \\
\hline \multirow{3}{*}{$\begin{array}{l}\text { S. silvestris (Vell.) H.S.Irwin \& Barneby } \\
\text { S. silvestris (Vell.) H.S.Irwin \& Barneby var. bifaria H.S.Irwin } \\
\& \text { Barneby } \\
\text { S. sophera (L.) Roxb. }\end{array}$} & 28 & Souza \& Benko-Iseppon 2004; Matos et al. 2011 \\
\hline & 28 & Resende et al. 2013 \\
\hline & 28 & Rice et al. 2015 \\
\hline \multirow{3}{*}{$\begin{array}{l}\text { S. spectabilis (DC.) H.S.Irwin \& Barneby } \\
\text { S. spectabilis (DC.) H.S.Irwin \& Barneby var. excelsa (Schrad- } \\
\text { er) H.S.Irwin \& Barneby } \\
\text { S. splendida (Vogel) H.S.Irwin \& Barneby }\end{array}$} & 26,28 & Rice et al. 2015; Resende et al. 2013 \\
\hline & 28 & Rice et al. 2015; Present work \\
\hline & 26 & Biondo et al. 2005a; Resende et al. 2013; Present work \\
\hline S. sulfurea (Collad.) H.S.Irwin \& Barneby & 28 & Rice et al. 2015 \\
\hline S. surattensis (Burm.f.) H.S.Irwin \& Barneby & 32 & Rice et al. 2015 \\
\hline S. timoriensis (DC.) H.S.Irwin \& Barneby & 28 & Rice et al. 2015 \\
\hline S. tora (L.) Roxb. & 26 & Rice et al. 2015 \\
\hline S. tropica (Vell.) H.S.Irwin \& Barneby & 28 & Biondo et al. 2005c \\
\hline S. venusta (F.Muell.) Randell & 28 & Matos et al. 2011 \\
\hline
\end{tabular}

\section{Cytogenetic and CMA/DAPI banding pattern analyses}

To analyze heterochromatin patterns, the root tips were pretreated with $0.002 \mathrm{M}$ 8-hydroxyquinoline (8-HQ) for 24 hours, fixed in 3:1 (v/v) absolute ethanol/glacial acetic acid for 30 minutes, and then stored in a freezer. For slide preparation, the roots were digested in a solution of $2 \%$ cellulase and $20 \%$ pectinase at $37^{\circ} \mathrm{C}$ for 40 minutes. 
Table 2. Principal karyological information concerning species of the genus Senna. Legend: $\mathrm{T}=$ terminal region of the chromosome, $\mathrm{P}=$ proximal region, $\mathrm{H}$ = heteromorphic band.

\begin{tabular}{|c|c|c|c|c|}
\hline Species & Vouchers & $2 n$ & Median size & Heterochromatin patterns \\
\hline Senna alata & JMPC - 1068 & 28 & $1.49 \mu \mathrm{m}$ & $6 \mathrm{~T} \mathrm{CMA}^{+} / \mathrm{DAPI}^{-}$ \\
\hline S. aversiflora & JMPC - 1066 & 56 & $1.96 \mu \mathrm{m}$ & $4 \mathrm{~T} \mathrm{CMA}^{+} / \mathrm{DAPI}^{-}$ \\
\hline S. georgica* & JMPC - 1067 & 26 & $2.11 \mu \mathrm{m}$ & $\begin{array}{l}4 \mathrm{~T} \mathrm{CMA}^{+} / \mathrm{DAPI}^{-} \\
22 \mathrm{P} \mathrm{CMA}^{+} / \mathrm{DAPI}^{-}\end{array}$ \\
\hline S. martiana & JMPC - 1070 & 28 & $2.00 \mu \mathrm{m}$ & $4 \mathrm{~T} \mathrm{CMA}^{+} / \mathrm{DAPI}^{-}$ \\
\hline S. obtusifolia & JMPC - 1146 & 26 & $2.78 \mu \mathrm{m}$ & $\begin{array}{l}2 \mathrm{~T} \mathrm{CMA}^{+} / \mathrm{DAPI}^{-} \\
24 \mathrm{P} \mathrm{CMA}^{+} / \mathrm{DAPI}^{-}\end{array}$ \\
\hline S. occidentalis & JMPC - 1072 & 28 & $2.25 \mu \mathrm{m}$ & $2 \mathrm{~T} \mathrm{CMA}^{+} / \mathrm{DAPI}^{-}$ \\
\hline S. rizzinii* & JMPC - 1069 & 26 & $2.19 \mu \mathrm{m}$ & $\begin{array}{l}4 \mathrm{~T} \mathrm{CMA}^{+} / \mathrm{DAPI}^{-} \\
22 \mathrm{P} \mathrm{CMA}^{+} / \mathrm{DAPI}^{-}\end{array}$ \\
\hline S. siamea & JMPC - 1071 & 28 & $2.01 \mu \mathrm{m}$ & $\begin{array}{c}6 \mathrm{~T} \mathrm{CMA}^{+} / \mathrm{DAPI}^{-} \\
1 \mathrm{PH} \mathrm{CMA}^{+} / \mathrm{DAPI}^{-}\end{array}$ \\
\hline S. spectabilis var. excelsa & JMPC - 1073 & 28 & $2.14 \mu \mathrm{m}$ & $\begin{array}{l}6 \mathrm{~T} \mathrm{CMA}^{+} / \mathrm{DAPI}^{-} \\
2 \mathrm{P} \mathrm{CMA}^{+} / \mathrm{DAPI}^{-}\end{array}$ \\
\hline S. splendida & JMPC - 1074 & 26 & $2.49 \mu \mathrm{m}$ & $\begin{array}{l}4 \mathrm{~T} \mathrm{CMA}^{+} / \mathrm{DAPI}^{-} \\
1 \mathrm{PH} \mathrm{CMA}^{+} / \mathrm{DAPI}^{-}\end{array}$ \\
\hline
\end{tabular}

* First chromosome count for the species

The root tips were squashed in $45 \%$ acetic acid, the slides frozen in liquid nitrogen to remove the coverslip. Slides were aged for three days and then stained for one hour with 10 $\mu \mathrm{L}$ of $\mathrm{CMA}(0.1 \mathrm{mg} / \mathrm{mL})$ followed by staining with $10 \mu \mathrm{L}$ DAPI $(1 \mu \mathrm{g} / \mathrm{mL})$ for $30 \mathrm{~min}$., with subsequent mounting in glycerin/McIlvaine buffer (pH 7.0) (1:1, v/v). Slides were held for three days in the dark to stabilize the fluorochromes (Guerra \& Souza 2002). Metaphases were recorded using a Zeiss microscope equipped with a Axio Cam MRC5 video camera, using Axiovision 4.8 software. At least three slides were analyzed for each species, generally photographing 10 cells per slide. Chromosome measurements were performed using Image Tool version 3.0 software (Donald et al. 2008). Chromosome morphologies were characterized using the centromeric index, following Guerra (1986). The images were edited using Adobe Photoshop CS3 Extended Version 10.0 software.

\section{Results}

\section{Chromosome Numbers in Senna}

The chromosome numbers of 72 species of the genus Senna were reviewed, and first counts were made for two species: Senna georgica $(2 n=26)$ and S. rizzinii $(2 n=26)$. Among them, 51 species ( $68.9 \%$ ) showed $2 n=28 ; 11$ species ( $14.8 \%$ ) showed $2 n=26 ; 10$ species showed $2 n=24$; three species showed $2 n=56$; and three others showed $2 n=42$; the numbers $2 n=112,104,32,22$ and 16 were recorded in only one species each (Tab. 1).

\section{Cytogenetic Analyses and CMA/DAPI Banding}

Among the 10 species analyzed here, Senna alata, S. martiana, S. occidentalis, S. siamea, and S. spectabilis var. excelsa showed $2 n=28$, while $S$. georgica, $S$. obtusifolia, $S$. rizzinii, and $S$. splendida showed $2 n=26$ (Fig. 1). Polyploidy was identified in S. aversiflora, with $2 n=56$ (Fig. 1B). The predominant chromosome morphology was metacentric to submetacentric, with the mean sizes of the karyotypes varying from $1.49 \mu \mathrm{m}$ in S. alata to $2.78 \mu \mathrm{m}$ in S. obtusifolia (Tab. 2).

CMA/DAPI banding analysis showed an occurrence of GC-rich base pairs $\left(\mathrm{CMA}^{+} / \mathrm{DAPI}^{-}\right)$preferentially located in the terminal chromosome regions of the chromosomes, corresponding to Nucleolar Organizing Regions (NORs). Heterochromatic bands located in proximal regions were observed in some species, such as $S$. obtusifolia, S. georgica, and $S$. rizzinii. There were also differences band numbers, which varied between two and six bands in the terminal chromosome regions, and between one and 24 bands in proximal regions (Fig. 1, Tab. 2). Two species, $S$. siamea and $S$. splendida, showed heteromorphic bands, with only one of the homologous chromosomes of each species showing $\mathrm{CMA}^{+}$/ $\mathrm{DAPI}^{-}$bands in their proximal region (Fig. $1 \mathrm{H}, \mathrm{J}$, arrows).

\section{Discussion}

The chromosome numbers recorded here for species of the genus Senna confirmed previous counts reported in the literature (Biondo et al. 2005a; Resende et al. 2013; Souza \& Benko-Iseppon 2004), with new records for $S$. georgica $(2 n=26)$ and $S$. rizzinii $(2 n=26)$.

The consistent records of $2 n=28$ in most species of Senna subjected to karyological analysis, especially in the basal clades (Marazzi et al. 2006), allied to that same number in diverse species of closely related genera (such as Cassia, Apuleia and Delonix [Biondo et al. 2005b; Rice et al. 2015]), confirms $x=14$ as the basic ancestral number of Senna, 

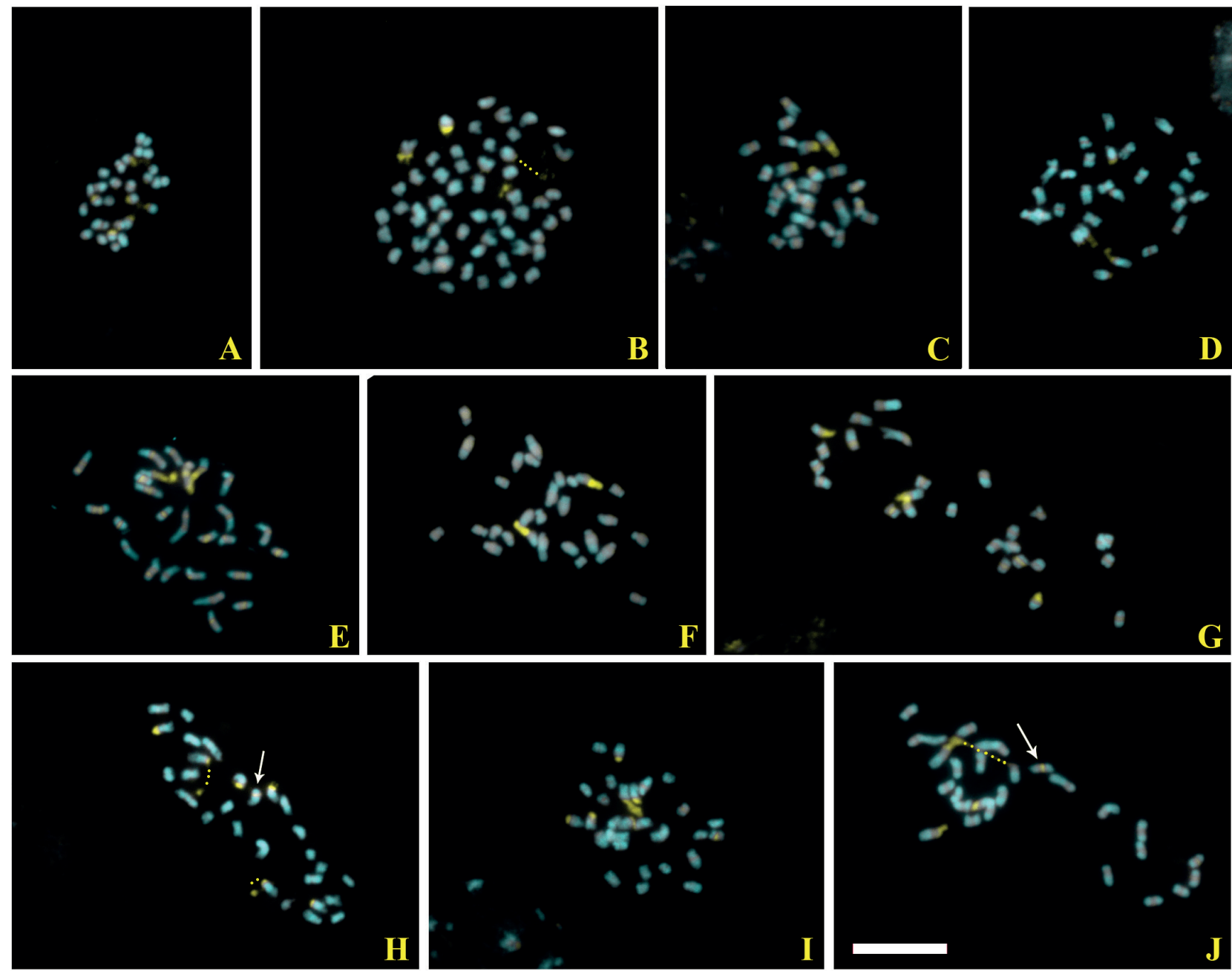

Figure 1. Mitotic metaphases and $\mathrm{CMA}^{+} / \mathrm{DAPI}^{-}$bands (yellow) in species of the genus Senna. A. Senna alata $(2 n=28) ;$ B. S. aversiflora $(2 n=56) ;$ C. S. georgica $(2 n=26)$; D. S. martiana $(2 n=28)$; E. S. obtusifolia $(2 n=26) ; \mathbf{F}$. S. occidentalis $(2 n=28) ; \mathbf{G} . S$. rizzinii $(2 n=26)$; H. $S$. siamea $(2 n=28)$; I. . spectabilis var. excelsa $(2 n=28)$; J. $S$. splendida $(2 n=26)$. The scale bar in J corresponds to $10 \mu \mathrm{m}$. Arrows in $\mathrm{H}$ and $\mathrm{J}$ indicate chromosomes with heteromorphic $\mathrm{CMA}^{+} / \mathrm{DAPI}^{-}$bands.

corroborating the positions of various authors (Goldblatt 1981; Biondo et al. 2005a).

Some species, such as S. occidentalis and S. obtusifolia, demonstrated intraspecific karyotypic variations, with karyotypes of $2 n=24,26$ and 28 (Chaulagain \& Sakya 2002; Biondo et al. 2005a; Rice et al. 2015). Diverse karyological phenomena may be involved in the intraspecific variations observed in different plant groups, especially neopolyploidy (species with diploid and polyploid cytotypes) and disploidy (centric fusions and fissions) (Guerra 2008). Additionally, polysomy and aneusomy (intra-individual variations in somatic chromosome numbers caused by polyploidy or aneuploidy respectively [Nirmala \& Rao 1996; Rodrigues et al. 2009]) have likely occurred in certain species of Senna (Chaulagain \& Sakya 2002; Matos et al. 2011), contributing to chromosome number variability in the genus. Intraspecific variations in chromosome numbers are quite common in other plant groups, such as Epidendrum secundum (Orchidaceae) (Assis et al. 2013), Rutidosis leptorrhynchoides (Asteraceae) (Murray \& Young 2001) and Zephyranthes sylvatica (Amaryllidaceae) (Felix et al. 2008). In those cases, intraspecific variations could be related to factors such as distance or geographic isolation, together with hybridization in natural populations. Intraspecific variations were also observed in Senna spectabilis, with records of $2 n=26$ and 28 (Resende et al. 2013; Rice et al. 2015), although those variations appear to be distinct at the variety level, as $S$. spectabilis var. excelsa shows $2 n=28$ in all of its karyotypic descriptions (including the present work), while $S$. spectabilis var. spectabilis generally shows $2 n=26$ (Rice et al. 2015).

Chromosome records of the genus Senna also demonstrated variations in ploidy levels, especially for S. rugosa $(2 n=42,56$ and 112; Resende et al. 2014), $S$. aversiflora ( $2 n=56$; Matos et al. 2011; present work) and S. gardneri ( $2 n=52$ and 104, Matos et al. 2011). Those 
variations could be a result of autopolyploidy, because hybridizations within the genus Senna are rarely viable, even among species having different morphotypes (see, for example, Holman \& Playford 2000).

In addition to intraspecific and ploidy-level variations, interspecific chromosome variations were also observed in Senna. Although $2 n=28$ predominated ( $68.9 \%$ of the species), there are significant numbers of records of $2 n=26$ $(14.8 \%)$ and $2 n=24(13.5 \%)$ among its species (Goldblatt 1981; Souza \& Benko-Iseppon 2004; Biondo et al. 2005a; Matos et al. 2011; Resende et al. 2013; Rice et al. 2015). Interspecific variations were observed in the present work, with five species showing $2 n=28$ but four species showing $2 n=26$. These numbers most likely represent disploidy events during the evolution of the genus, although they are generally treated as random phenomena (Goldblatt 1981; Biondo et al. 2005a; Resende et al. 2013).

Phylogenetic analyses undertaken by Marazzi et al. (2006) demonstrated that the genus Senna can be divided into seven monophyletic clades. Chromosome count comparisons with the results of those phylogenetic analyses can facilitate our understanding of interspecific variations. The prevalence of $2 n=28$ is observed in essentially all of the seven clades of Senna, especially in the most primitive and most derived clades. Most variations $(x=11,13,21$ and 28), on the other hand, occur in clade IV. That clade corresponds to the monophyletic series Bacillaris (section Chamaefistula), which comprises approximately 50 species of shrubs and small trees whose leaves are exclusively composed of two pairs of folioles (Irwin \& Barneby 1982; Marazzi et al. 2006). Most chromosome records of $x=13$ occur in clade IVb. Phylogenetic analyses point to a large polytomy among the species that compose that clade, indicating its probable recent radiation (Marazzi et al. 2006); the clade probably experienced a disploidy event ( $x$ $=13$ ) in a common ancestor, with most of the descendent species then conserving that cytological characteristic. Other variations, such as $x=12$ in $S$. atomaria and $x=13$ in S. spectabilis (clade III), $x=12$ in S. multijuga (clade VI), and $x=12$ in S. hirsuta var. hirta (clade VIIb) were also apparently important for the diversification of the genus, although with lesser evolutive significance in terms of their respective clades.

In relation to heterochromatin patterns, significant differences were observed among most of the species of the genus Senna analyzed, whether in terms of the numbers of bands (2-26) or their localizations on the chromosomes (terminal or proximal). Only S. georgica and S. rizzinii demonstrated the same banding pattern (four terminal $\mathrm{CMA}^{+} / \mathrm{DAPI}^{-}$and 22 proximal $\mathrm{CMA}^{+} / \mathrm{DAPI}^{-}$bands). Senna martiana and $S$. aversiflora demonstrated the same numbers of bands (four terminal $\mathrm{CMA}^{+} / \mathrm{DAPI}^{-}$bands), although the latter demonstrated a polyploid karyotype $(2 n=52)$. Variations in heterochromatic banding patterns are quite common in plant groups and can vary among species, populations, or even individuals (Guerra 2000; Dobigny et al. 2004). Those variations can reflect the results of various cytological phenomena, especially satellite DNA amplification (Guerra 2000; Silva et al. 2010; Ribeiro et al. 2016). Differences in heterochromatic banding patterns are quite useful for cytotaxonomic characterizations of plant species, especially among those having karyotypes formed by morphologically similar chromosomes that are numerically stable (Guerra 2000; Scaldaferro et al. 2012; Cordeiro et al. 2016). The observed differences in the CMA/ DAPI banding patterns in Senna ratified the effectiveness of that technique for facilitating karyological differentiation of its species.

Among the 10 species analyzed, only three (S. alata, S. obtusifolia, and $S$. siamea) had previously been examined in terms of their CMA/DAPI banding patterns (Souza \& BenkoIseppon 2004). Those species did, however, demonstrate differences when compared to the analyses performed here. Senna alata, S. obtusifolia, and S. siamea had previously been reported to have two terminal $\mathrm{CMA}^{+} / \mathrm{DAPI}^{-}$bands (Souza \& Benko-Iseppon 2004), while we found those same species to have six terminal $\mathrm{CMA}^{+} / \mathrm{DAPI}^{-}$bands, two terminal $\mathrm{CMA}^{+}$/ $\mathrm{DAPI}^{-}+24$ proximal $\mathrm{CMA}^{+} / \mathrm{DAPI}^{-}$bands, and six terminal $\mathrm{CMA}^{+} / \mathrm{DAPI}^{-}$bands plus one proximal heteromorphic band respectively. Differences in heterochromatin patterns within the same species can occur in distinct populations, as was previously reported by Souza \& Benko-Iseppon (2004) in S. obtusifolia; those authors found one population having two terminal $\mathrm{CMA}^{+} / \mathrm{DAPI}^{-}$bands and another showing two terminal $\mathrm{DAPI}^{+} / \mathrm{CMA}^{-}$bands. Variations in the patterns of heterochromatic bands in different individuals of the same species are often observed in plants, including Oziroë argentinensis (Dematteis et al. 2006), Capsicum (Scaldaferro et al. 2012), Allium pulchellum (Vosa 1996), and Pinus nigra (Bogunić et al. 2011). Variations in heterochromatin bands between individuals of the same species appear to be an intraspecific cytological characteristic of the genus Senna that is worthy of further investigation, calling for the analysis of distinct populations from different ecosystems and different geographic regions.

The present study allowed us to put forward the following general considerations: a) CMA/DAPI banding patterns in the genus Senna are quite useful for cytotaxonomically differentiating its species, although possible variations between different populations of a given species will need to be closely examined; b) although most species of Senna show $2 n=28$, records of polyploidy $(2 n=52,56,104$ and $112)$ and disploidy $(2 n=22,24$ and 26$)$ were observed in numerous species of that genus; c) intraspecific variations observed in certain species, such as $S$. obtusifolia and $S$. occidentalis, appeared to be result of cytological phenomena such as disploidy, or polysomy and aneusomy.

The karyotypic variations observed in Senna, whether interspecific or intraspecific, probably contributed to the diversification of that genus, making it one of the most 
representative taxa of the Leguminosae in many different regions of the world.

\section{References}

Acharya L, Mukherjee AK, Panda PC. 2011. Separation of the genera in the subtribe Cassiinae (Leguminosae: Caesalpinioidae) using molecular markers. Acta Botanica Brasilica 25: 223-233.

Almeida EM, Wanderley AM, Nollet F, Costa FR, Souza LGR, Felix LP. 2016. A new species of Ameroglossum (Schrophulariaceae) growing on inselbergs in Northeastern Brazil. Systematic Botany 41: 423-429.

Assis FNM, Souza BCQ, Medeiros-Neto E, Pinheiro F, Silva AEB, Felix LP. 2013. Karyology of the genus Epidendrum (Orchidaceae: Laeliinae) with emphasis on subgenus Amphiglottium and chromosome number variability in Epidendrum secundum. Botanical Journal of the Linnean Society 172: 329-344.

Biondo E, Miotto STS, Schifino-Wittmann MT. 2005b. Números cromossômicos e implicações sistemáticas em espécies da subfamília Caesalpinioideae (Leguminosae) ocorrentes na região sul do Brasil. Revista Brasileira de Botânica 28: 797-808.

Biondo E, Miotto STS, Schifino-Wittmann MT. 2005c. Citogenética de espécies arbóreas da subfamília Caesalpinioideae - Leguminosae do Sul do Brasil. Ciência Florestal 15: 241-248.

Biondo E, Miotto STS, Schifino-Wittmann MT, Castro B. 2005 a. Cytogenetics and cytotaxonomy of Brazilian species of Senna Mill. (Cassieae-Caesalpinioideae-Leguminosae). Caryologia 58: 152-163.

Bogunić F, Siljak-Yakovlev S, Muratović E, Ballian D. 2011. Different karyotype patterns among allopatric Pinus nigra (Pinaceae) populations revealed by molecular cytogenetics. Plant Biology 13: 194-200.

Chaulagain BP, Sakya SR. 2002. Inconstancy in chromosome number in some species of Cassia L. found in Nepal. Nepal Journal of Science and Technology 4: 123-128.

Cordeiro JMP, Lima SAA, Paz SN, Santos AMS, Felix LP. 2016. Karyotype evolution in the genus Jacaranda Juss. (Jacarandeae, Bignoniaceae): chromosome numbers and heterocromatin. Genetics and Molecular Research 15(4). DOI: http://dx.doi.org/10.4238/gmr15048973.

Dematteis M, Fernández A, Acosta AD. 2006. Heterochromatin variation in Oziroë argentinensis (Hyacinthaceae) revealed by florescent banding. Caryologia 59: 104-111.

Dobigny G, Ducroz JF, Robinson TJ, Volobouev V. 2004. Cytogenetics and cladistics. Systematic Biology 53: 470-484.

Donald C, Brent DS, Mcdavid WD, Greer DD. 2008. Uthscsa. Image Tool (IT) - Version 3.0. http://ddsdx.uthscsa.edu/dig/download.html. 10 Apr. 2017.

Felix WJP, Dutilh JHA, Melo NF, Fernandes AA, Felix LP. 2008. Intrapopulational chromosome number variation in Zephyranthes sylvatica Baker (Amaryllidaceae: Hippeastreae) from Northeast Brazil. Revista Brasileira de Botânica 31: 371-375.

Goldblatt P. 1981. Cytology and the phylogeny of Leguminosae. In: Polhill RM, Raven PH. (eds.) Advances in Legume systematics. Vol. 2. Kew, Royal Botanical Garden. p. 427-463.

Guerra M. 1986. Reviewing the chromosome nomenclature of Levan et al. Revista Brasileira de Genética 9: 741-743.
Guerra M. 2000. Patterns of heterochromatin distribution in plant chromosomes. Genetics and Molecular Biology 23: 1029-1041.

Guerra M. 2008. Chromosome numbers in plant cytotaxonomy: concepts and implications. Cytogenetic and Genome Research 120: 339-350.

Guerra M, Souza M.J. 2002. Como observar cromossomos: Um guia de técnicas em citogenética vegetal, animal e humana. Ribeirão Preto, FUNPEC.

Holman JE, Playford J. 2000. Molecular and morphological variation in the Senna artemisioides complex. Australian Journal of Botany 48: 569-579.

Irwin HS, Barneby RC. 1982. The American Cassiinae - a synoptical revision of Leguminosae tribe Cassiae subtribe Cassiinae in the New World. Memoirs of the New York Botanical Garden 35: 1-918.

Marazzi B, Endress PK, Queiroz LP, Conti E. 2006. Phylogenetic relationships within Senna (Leguminosae, Cassiinae) based on three chloroplast DNA regions: patterns in the evolution of floral symmetry and extrafloral nectaries. American Journal of Botany 93: 288-303.

Matos LP, Barreto KL, Conceição AS, Queiroz LP, Andrade MJG. 2011. Análise citogenética em 16 espécies dos gêneros Senna Mill. e Cassia L. (Leguminosae), com ênfase nas espécies ocorrentes na Bahia. In: XV Semic - Seminário de Iniciação Científica. Feira de Santana, Universidade Estadual de Feira de Santana. p. 114-117.

Murray BG, Young AG. 2001. Widespread chromosome variation in the endangered grassland forb Rutidosis leptorrhynchoides F. Muell. (Asteraceae: Gnaphalieae). Annals of Botany 87: 1-8.

Nirmala A, Rao PN. 1996. Genesis of chromosome numerical mosaicism in higher plants. The Nucleus, Lahore 39: 151-175.

Pessoa E, Felix LP, Alves M. 2014. A new Epidendrum (Laeliinae-Orchidaceae) from the Atlantic Forest of northeastern Brazil: evidence from morphology and cytogenetics. Brittonia 66: 347-352.

Resende KFM, Davide LC, Torres GA. 2013. Chromosome number and meiosis in populations of Senna species (Caesalpinioideae - Fabaceae) from Southeast Brazil. Caryologia 66: 1-5.

Resende KFM, Prado C, Davide L, Torres G. 2014. Polyploidy and apomixis in accessions of Senna rugosa (G.Don) H.S.Irwin \& Barneby. Turkish Journal of Biology 38: 510-515.

Ribeiro T, Marques A, Novák P, et al. 2016. Centromeric and non-centromeric satellite DNA organisation differs in holocentric Rhynchospora species. Chromosoma 126: 325-335.

Rice A, Glick L, Abadi S, et al. 2015. The Chromosome Counts Database (CCDB) - a community resource of plant chromosome numbers. New Phytologist 206: 19-26.

Rodrigues RS, Corrêa AM, Forni-Martins E, Tozzi AMGA. 2009. Números cromossômicos em espécies de Acosmium Schott e Leptolobium Vogel (Leguminosae, Papilionoideae). Acta Botanica Brasilica 23: 902-906.

Scaldaferro MA, Grabiele M, Moscone EA. 2012. Heterocromatin type, amount and distribution in wild species of chili peppers (Capsicum, Solanaceae). Genetic Resources and Crop Evolution 60: 693-709.

Silva AEB, Marques A, Santos KGB, Guerra M. 2010. The evolution of CMA bands in Citrus and related genera. Chromosome Research 18: 503-514.

Souza MGC, Benko-Iseppon AM. 2004. Cytogenetics and chromosome banding patterns in Caesalpinioideae and Papilionioideae species of Pará, Amazonas, Brazil. Botanical Journal of the Linnean Society 144: 181-191.

Vosa C. 1996. Some aspects of karyotype evolution in Liliflorae: heterochromatin variation and ecology in Allium pulchellum. Bocconea 5: 267-270. 